\title{
THE FACTORS INFLUENCING BUSINESS ONLINE ENTREPENEURS IN CHOOSING DELIVERY SERVICE
}

\author{
Andre Yosafat ${ }^{1}$, Ivan Sadrakh ${ }^{2}$, Juliater Simarmata ${ }^{3}$, Hiskia \\ Simarmata ${ }^{4}$ \\ 1. STMT Trisakti, 2. STMT Trisakti, 3. STMT Trisakti, 4. STMT Trisakti \\ corresponding author: andre.yosafat@gmail.com
}

\begin{abstract}
The development of technology and information to make millennial society now began to change the way shopping that initially shop conventionally to shop online, The rapid growth of e-commerce market share in Indonesia is already no doubt. With the number of internet users reaching the number 82 million people or about $30 \%$ of the total population in Indonesia, the e-commerce market into a gold mine is very tempting for some people who can see the potential for the future. This growth is supported by data from the Minister of Communications which states that the value of e-commerce transactions in 2013 reached Rp130 trillion, so that online business is now starting to grow and many people become online business, this makes the online business requires a service delivery right to send the goods to the buyer, there are some companies that are well known delivery service delivery by the community such as TIKI (Titipan Kilat), JNE, SICEPAT, J \& T EXPRESS, in this study researchers conducted a survey of 34 respondents of online business and in this study researchers only choose 2 companies that have TIKI brand image and $\mathbf{J} \&$ T Express company which is a startup company that is in demand by online business, the aspect that will be compared between 2 companies is Brand Image, Price, Kind of Service, Service Quality, \& Service innovation with comparative TIKI results Brand and J \& T express at an affordable price.
\end{abstract}

Keywords: online business ,brand image, delivery service, price, service quality, ecommerce, service innovation

\section{Introduction}

The rapid growth of e-commerce market in Indonesia is no doubt. With the number of internet users reaching the number 82 million people or about $30 \%$ of the total population in Indonesia, the e-commerce market into a gold mine is very tempting for some people who can see the potential for the future. This growth is supported by data from the Minister of Communication and Information which states that the value of e-commerce transactions in 2013 reached Rp130 trillion.

This is a fantastic number considering that only about $7 \%$ of internet users in Indonesia have ever been shopping online, this is based on data from McKinsey and since 2014 Euromonitor noted, online sales in Indonesia has 
reached US \$ 1.1 billion. If we see Indonesia as a vast archipelagic country, e-commerce is a potentially huge growth market in Indonesia The growing number of online businesspeople in Indonesia and the large number of consumer demand makes many people see the opportunity to set up shipping companies to help businesses online deliver the goods to the buyer. In Indonesia the level of competition for freight forwarding services is increasing with the aim of marketing all over Indonesia, as evidenced by the increasing number of shipping service companies in the last 5 years.

The tight competition starts from the cost of the offered offer, the type of services and services provided by each delivery service company to the potential service user

TIKI is one of the long established company in Indonesia. With a brand that has been widely known by the people in Indonesia. But along with the increase of shipping service company one of them $\mathrm{J} \& \mathrm{~T}$ EXPRESS which provides cheap shipping cost and fast delivery service.

TIKI and $\mathrm{J} \& \mathrm{~T}$ EXPRESS Demanded to improve their performance in terms of brand aspect, service quality, type of service to meet the desires and needs of service users in this case online business.

Thus the authors plan to conduct a study entitled "FACTOR INFLUENCING ONLINE BUSSINES IN CHOOSING DELIVERY SERVICE “

Brand Image

TIKI \& J\&T the brand names which have been known by the online business entrepreneurs. Brand is an identity which can be easily identified, and it promises certain values (Lee, Lee, \& Wu, 2011). (Rindell, Korkman, \& Gummerus, 2011) the importance of brand image development in business organizations. Brand image is a rational and emotional perception on a particular brand (Koubaa, 2008).) Whereas in the higher level of competition, brand contributes to making and maintaining the competitiveness of a product. Brand will be associated with a specific image 
which is able to give a certain association in consumer's mind. In their development, companies are getting aware of brand as the most valuable company asset. Brand is internalization of a number of impressions received by customers and consumers which occupies a specific position in their memory toward the emotional and functional benefits that are perceived. (Mourad, Ennew, \& Kortam, 2011)

Price

The prices offered by the delivery service companies are very competitive between each other in accordance with the type of delivery required. Price is an absolute thing to be taken into account by a businessman in the production process, from which the profit is obtained (Lee, Lee, \& Wu, 2011). the definition of price according to (Kuo \& Nakhata, 2016) is that: "Price is the combined result of good and service transaction by demand and supply in the market". The theory of pricing as proposed by (Bahmani, Harvey \& Hegerty, 2013) states that: "Price is determined mutually in the interaction between the producer and consumer or, in the technical term, mutually by demand and supply, or it can also be said that the balanced output of a commodity is in the equilibrium between the price of demand and the price of supply". Pricing is intended to be a strategy for the company to compete and the predetermined objective should be consistent with the way to determine its relative position in the competition. Pricing is not regarded as easy for a company since the decision of price is influenced by some factors, both internal and external factors. In setting the price with orientation to primary demand, a company believes that lower price can increase the number of users or level of utilization or repeat purchase for a certain product category. It is because the most important thing here is that it can attract new customers.

Service Quality.

Service quality is one of the factors that determine the selection of services or products. Service quality is one of the factors that determine the selection of services or products. (Zehir \& Narcıkara, 2016). The definition of service 
quality according to (Zeithaml and Bitner, 1996) service quality can be defined as an overall judgment similar to attitude towards the service and generally accepted as an antecedent of overall customer satisfaction. The theory of service Quality as proposed by Parasuraman et al. (1988) is the ability of the organization to meet or exceed customer expectations. It is the difference between customer expectations of service and perceived service

Service Innovation

The diversity of service activities means that service innovations and innovation processes take various forms(Miles, 2008). Service innovation is needed in a very tight competition to attract customers. Many accounts of service innovation underscore the importance of the role of the client in coproducing services (Carvalho \& Goodyear, 2017)

\section{Method}

This research uses questionnaire as a data collection tool (Singh \& Crisafulli, 2016); The next stage is analyzing and interpreting the data obtained in the field using descriptive statistical analysis. The total sample of 34 business online Entrepreneur in Jakarta. The distribution of questionnaire is carried out randomly regarding (Bogicevic, Yang, Bilgihan, $\&$ Bujisic, 2013). The duration of survey is one month (in the period of 1121October 2017) using google form.

Whereas the operationalization of research variables can be seen in figure 3.1 below:

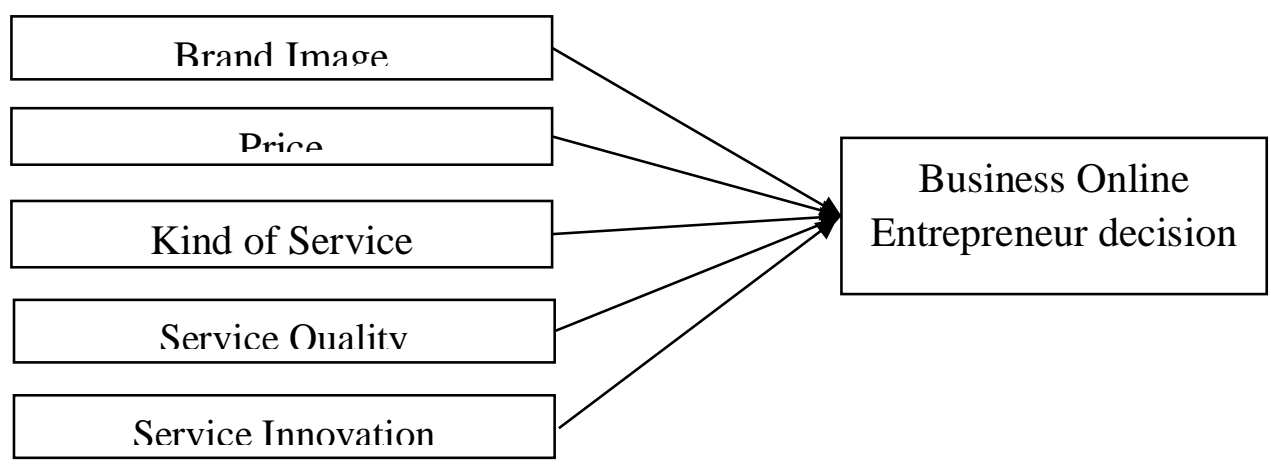

Figure 3.1 Conceptual Frame 


\section{Discussion and Results}

Table 1 shows the mean and S.D results for these variables: brand image, price, service quality, service innovation. The result found that the Online business responses were in agreed level which the mean $=3.27$ and S.D $=0.71$, Mean of Service Quality $=3.65$. Mean of Brand Image $=3.40$. Mean of Price $=3.26$. Mean of service innovation $=2.75$.

Table 1

The Factor influencing business online entrepreneurs in choosing TIKI

\begin{tabular}{|l|c|c|}
\hline \multicolumn{1}{|c|}{ Variables } & Mean & S.D \\
\hline Service Quality & 3.65 & 0.67 \\
\hline Brand Image & 3.40 & 1.03 \\
\hline Price & 3.26 & 0.75 \\
\hline Service Innovation & 2.75 & 0.98 \\
\hline Average & 3.27 & 0.71 \\
\hline
\end{tabular}

Table 2 shows the mean and S.D results for these variables: brand image, price, service quality, service innovation. The result found that the Online business responses were in agreed level which the mean $=3.26$ and S.D $=0.86$, Mean of Service Quality $=3.42$. Mean of Brand Image $=3.33$. Mean of Price $=3.20$. Mean of service innovation $=3.10$.

Table 2

The Factor influencing business online entrepreneurs in choosing J\&T EXPRESS

\begin{tabular}{|l|c|c|}
\hline \multicolumn{1}{|c|}{ Variables } & Mean & S.D \\
\hline Service Quality & 3.42 & 0.67 \\
\hline Brand Image & 3.33 & 1.19 \\
\hline Price & 3.20 & 0.73 \\
\hline Service Innovation & 3.10 & 1.17 \\
\hline Average & 3.26 & 0.86 \\
\hline
\end{tabular}

\section{Conclusion}

Research data obtained about the factors that affect the business of online entrepreneurs in choosing to provide services in terms of quality TIKI services better than the $\mathrm{J} \& \mathrm{~T}$ Express and in the brand TIKI brand image is 
superior compared to $\mathrm{J} \& \mathrm{~T}$ EXPRESS and price terms TIKI the price offered by TIKI is more affordable compared to $\mathrm{J} \& \mathrm{~T}$ EXPRESS but in Service side J\&T EXPRESS innovation is superior compared to TIKI

TIKI must improve service innovation for better future and for $\mathrm{J} \& \mathrm{~T}$ EXPRESS must improve the quality of service to customers in this case online business and do promotion and advertisement to strengthen brand image to society and issue to online businessman to get to know company $\mathbf{J}$ \& $\mathrm{T}$ EXPRESS, and provide competitive pricing so that many online businesses use J \& T EXPRESS services.

\section{References}

Bahmani, M., Harvey, H., \& Hegerty, S. W. (2013). Empirical Tests of the Marshall-Lerner Condition: A Literature Review. Journal of Economic Studies (Vol. 40). https://doi.org/10.1108/01443581311283989

Bogicevic, V., Yang, W., Bilgihan, A., \& Bujisic, M. (2013). Airport service quality drivers of passenger satisfaction. Tourism Review, 68(4), 3-18. https://doi.org/10.1108/TR-09-2013-0047

Carvalho, L., \& Goodyear, P. (2017). Design, learning networks and service innovation. Design Studies, 1-27. https://doi.org/10.1016/j.destud.2017.09.003

Koubaa, Y. (2008). Country of origin, brand image perception, and brand image structure. Asia Pacific Journal of Marketing and Logistics, 20(2), 139-155. https://doi.org/10.1108/13555850810864524

Kuo, H.-C., \& Nakhata, C. (2016). Price promotions and products with low consumer ratings. Journal of Consumer Marketing, 33(7), 517-527. https://doi.org/10.1108/JCM-04-2016-1767

Lee, H., Lee, C., \& Wu, C. (2011). Brand image strategy affects brand equity after M\&amp;A. European Journal of Marketing, 45(7/8), 1091-1111. https://doi.org/10.1108/03090561111137624

Miles, I. (2008). Patterns of innovation in service industries. IBM Systems Journal, 47(1), 115-128. https://doi.org/10.1147/sj.471.0115

Mourad, M., Ennew, C., \& Kortam, W. (2011). Brand equity in higher education. Marketing Intelligence \& Planning, 29(4), 403-420. https://doi.org/10.1108/02634501111138563

Rindell, A., Korkman, O., \& Gummerus, J. (2011). The role of brand images in consumer practices: uncovering embedded brand strength. Journal of Product \& Brand Management, 20(6), 440-446. https://doi.org/10.1108/10610421111166586

Simarmata, J., \& Ikhsan, R. B. (2017). Building Customer Retention in on-Line, 15(2), 229-239. https://doi.org/10.17512/pjms.2017.15.2.21

Simarmata, J., Rs, M., Keke, Y., \& Panjaitan, F. (2016). the Airline Customer'S Buying Decision Through Online Travel Agent: a Case Study of the Passengers of Scheduled Domestic Airlines in Indonesia. International Journal of Economics, Commerce and Management United Kingdom, 3(3), 335-349. Retrieved from http://ijecm.co.uk/ 
Simarmata J, Charles A.N, Analysis and Evaluation on the Strategy of Indonesian Airline Companies to Face the Increasing Price of Avtur and the Decreasing Exchange Value of Rupiah, against the US Dollar, http://www.dpu.ac.th/masean/upload/content/files/019\%20Analysis\%20and\% 20Evaluation $\% 20$ on $\% 20$ the $\% 20$ Strategy $\% 20$ of $\% 20$ Indonesian $\% 20$ Airline $\%$ 20Companies.pdf

Singh, J., \& Crisafulli, B. (2015). Managing online service recovery: procedures, justice and customer satisfaction. Journal of Service Theory and Practice (Vol. 26). https://doi.org/10.1108/JSTP-01-2015-0013

Yuliatini, Fachry Ashar, Wynd Rizaldy (2015). Strategies in enhancing the quality services of traffic special division. Vol 2, No 1 (2015) http://library.stmttrisakti.ac.id/jurnal/index.php/JMBTL/article/view/34

Zehir, C., \& Narcikara, E. (2016). E-Service Quality and E-Recovery Service Quality: Effects on Value Perceptions and Loyalty Intentions. Procedia Social and Behavioral Sciences, 229, 427-443. https://doi.org/10.1016/j.sbspro.2016.07.153

Zeithaml, V. A., Berry, L. L., \& Parasuraman, A. (1996). The Behavioral Consequences of Service Quality. Journal of Marketing, 60(2), 31. https://doi.org/10.2307/1251929 